\title{
ARAP AKINLARINA KADAR ARTVIN VE ÇEVRESi
}

\section{Artvin and lts Surroundings until Arabian Invasion}

\section{Dr. Ömer SUBAŞI*}

\section{ÖZET}

Klarceti Bölgesi, Artvin, Ardanuç, Şavşat, Borçka ve Murgul ile tarihi kaynaklarda isminden sıkça bahsedilen Tukharis'ten oluşmaktadır. Bölge, coğrafi olarak, Çoruh Nehri'nin aşağı kesimlerinden, Yanlızçam Dağları́nın batısına, oradan da Şavşat ve Artvin'in güneyinden Karadeniz'e kadar uzanan toprakları kapsamaktadır. Klarceti, tarihi kaynaklarda dönem dönem farklı isimlerle anılmıştır. Klarceti Bölgesi'nin tarihi, Urartu akınlarının bölgeye ulaşması ile başlar ve ilk Urartu kaynaklarında Katarza olarak geçmekte olan bölge ismi sonraki yüzyıllarda Choranzene ve ardından da Klarceti olarak değişir. Klarceti, Urartu etkisinin azaldığı bir dönemde Kafkaslardan gelen ìskit akınlarına maruz kalmış ve iskitler, bölgede yaklaşık iki yüzyıl yaşadıktan sonra Klarceti ve çevresi Gogarene Bölgesi olarak anılmaya başlanmıştır. Bölgede kurulan ilk siyasi otorite olan Parnavazi sülalesinin hakimiyeti, Armenia Bölgesi yönetici sınıfının da mensubu olduğu Arsasid Hanedanlığı' nın bölgeye hakimiyeti ile son bulmuş ve ardından bölgede iberia, Armenia, Roma, Bizans ve Sasani mücadelesi yoğun bir şekilde yaşanmıştır. Bu çalışmada Klarceti Bölgesi' nin tarih sahnesine çıkışı, bölge üzerindeki iberia, Armenia, Roma, Bizans ve Sasani mücadeleleri ile bölgeye gerçekleştirilen Müslüman Arap akınları ele alınmıştır.

Anahtar Sözcükler: Klarceti, Artvin. Ardanuç, Şavşat, Borçka, Tukharis, Iberia, Armenia, Arap, Bizans.

\section{ABSTRACT}

The region "Klarceti" was comprised of Artvin, Ardanuç, Şavşat, Borçka, Murgul and the region "Tukharis", which is often mentioned in historical sources. The region, geographically, covers the land from the lower parts of the River Coruh to the West part of Yalnızçam Mountains and from the South of Şavşat and Artvin to the Black Sea. There have been many names used for "Klarceti" from time to time in historical sources. The history of Klarceti Region begins with the Urartu invasion in the region. The region was called "Katarza" in the first Urartu resources and then named as "Choranzene" and "Klarceti", afterwards. Klarceti was subjected to Scythian invasion at the time when there was little Urartu effect and the Klarceti Region and its surroundings was called "Gogarene Region" after Scythians lived about 200 years in the vicinity. The domination of "Parnavazi" Dynasty, the first political authority in the region, ended when the Arsidad Dynasty, which also includes the head class of Armenia Region, dominated the region. Afterwards, intense struggles of Iberia, Armenia, Rome, Byzantine and Sasanid were observed in the region. In this study, we talk about the appearance of the region "Klarceti" in the scene of history; lberian, Armenian, Roman, Byzantian and Sasani battles together with Muslim Arabian invasions in the region.

Key Words: Klarceti, Artvin, Ardanuç, Şavşat, Borçka, Tukharis, iberia, Armenia, Arabian, Byzantine.

\footnotetext{
*Artvin Çoruh Ünv. Fen Edebiyat Fak. Tarih Bölümü Öğretim Üyesi, subasi.omer25@gmail.com
} 


\section{Giriş}

Artvin ve çevresinden, isim olarak olmasa da bölge olarak ilk bahseden Urartulardır. Urartu Krallığı' zamanında kuzeye ilk seferler Kral işspuini (M.Ö. 825-810) ve oğlu Miuna (M.Ö. 810-780) döneminde olduğu bilinmektedir. Bu kralların yaptıkları seferler sonrası Luşa, Witerhu ve Katarza'dan büyük miktarda ganimetlerle döndükleri yazıtlarda anlatılmaktadır. ${ }^{2}$ Kuzeye ilk seferlerin düzenlendiği işpuini döneminde bu ülkelerden alınan ganimetler; erkek, kadın, at, küçük ve büyükbaş hayvanlardan oluşmaktaydı. ${ }^{3}$ Minua'nın oğlu I. Argişti (M.Ö. 780-756) döneminde kuzeye yapılan seferlerin anlatıldığı ve Argişti yıllığı olarak bilinen Horhor Yazıtı'nda, kral tarafından kuzeye yapılan sefer sonrası alınan yerler arasında ismi geçen birçok yerleşim yeri içerisinde Katarza ${ }^{4}$ ve Diauehi'de ${ }^{5}$ bulunmaktadır. ${ }^{6}$ VIll. yüzyıla gelindiğinde Asur yazıtlarına göre Kimmerler'in Güney Kafkasya'da gözükmesi ll. Sargon (M.Ö.722-705) idaresinin son dönemine denk gelmektedir. İskitlerin göç yolları üzerinden çekilerek güneye yönelen Kimmerler'in ilk ulaştığı saha iberia düzlükleri oldu. iberia Bölgesi' nin siyasi vaziyetini baştan sona değiştiren Kimmerler, M.Ö. IX-VIIl. yüzyıllarda politik ve kültürel yükselmenin doruklarına çıkmış olan Kolkhis Krallığı'nın ${ }^{7}$ M.Ö. VIl. yüzyıl içerisinde yıkılmasına sebep oldular. ${ }^{8}$ Kimmer akınlarını ${ }^{9} \mathrm{i}_{c ̧}$ Anadolu'ya yönlendirerek yıkılmaktan kurtulan Urartu Devleti, M.Ö. VIl. yüzyıl başında İskit akınlarını durduramayarak ortadan kalktılar. Kartlos'un batısında Urartuların güç kaybetmesi ile ortaya çıkan boşluğu değerlendiren ìskitler (Goglar), Il. Rousas (Rusa M.Ö. 685-645) döneminde (M.Ö. 665 yılından itibaren) Kür Nehri'nin sağ tarafinı ele geçirerek Gogarene, ya da kendi isimleriyle Sakasen ${ }^{10}$ olarak anılan bölgeyi yurt tuttular." Gogaren ismi Strabon'da Gogarene olarak geçmekte, Albania'ya ve Kür nehri ile sınırında olduğu ve Sakasen isminin sonradan Gogarene olarak anıldığı aktarmakta, ${ }^{2}$ P'awstos Buzandac'i' (Faustus) ismi Gurark olarak vermektedir. ${ }^{13}$ Ananias ise bu bölgenin dokuz vilayetten oluştuğunu bildirmektedir. Bunlar Jorop'or, Kolbap'or, Cobap'or, Tasir, T'relk, Kankark, Upper Jawaxk, Artanhan ve Kalarck'dır (Klarcet). ${ }^{14} \quad$ Klarceti Bölgesi' nin de içerisinde bulunduğu Gogarane Bölgesi, ${ }^{15}$ bir yüzyıldan fazla ìskit hâkimiyetinde kaldıktan sonra 1. Darius (M.Ö. 522-485) zamanında Pers İmparatorluğu'na M.Ö. 519 yılındaki İskit seferi sırasında katılmış ve Heredot'un aktarımlarına göre, Darius ülkesini 20 satraplığa böldükten sonra Matienler (Urmiye Gölü ve çevresi), Saspeirler (Çoruh boyu ve çevresi-ispir'de isimleri yaşayan Saperler) ${ }^{16}$ ve Alarodialılar (Varto ve Van Gölünün çevresi) on sekizinci satraplık, Moskhililer (Yukarı-Kür boyunda Gogarene Çevresi-Moschic-Meschia-Camili), ${ }^{17}$ Makronai (Yunanca Kocabaşılılar anlamında, Balkar Dağları ile Karadeniz arasında sonraki Lazların ataları), Tiberanliler (Yunanca Ağaçevliler) ve Mossyoikia ise on dokuzuncu satraplık olarak düzenlemişti. Klarceti'nin de içerisinde bulunduğu bu bölgeler yaklaşık 11 asır boyunca İranlıların hakimiyetinde kalmıştır. ${ }^{18}$ M.Ö. 400 yılında Doğu Anadolu ve Doğu Karadeniz üzerinden Trabzon'a ulaşan Ksenphon, yukarıda ismi geçen bölgelerde yaşayan halklar hakkında detaylı gözlemlerini anlatmakta ve Sakasen bölgesinin sınırlarını batıda Çoruh nehrine kadar ulaştığını aktarmaktadır. ${ }^{19}$

\section{Arap Akınlarına Kadar Artvin ve Çevresinin Siyasi Tarihi}

Günümüzde, Artvin ili ve ilçeleri Ardanuç, Şavşat, Borçka ile Murgul'u içerisine alan; ayrıca tarihi kaynaklarda isminden sıkça bahsedilen Tukharis isimli yerleşim yerinden 
oluşan Klarceti Bölgesi' nin ${ }^{20}$ siyasi tarihi IV. yüzyılda Büyük İskender'in (M.Ö.356-323) akınları ile başlar. Batıdan hareket eden İskender M.Ö. 336'da Çoruh boylarına ulaştı ve Gogarene (Sakasen) bölgesinden doğuda Hazar Denizi kıyısına kadar uzanan, iberia'daki Tsunda'yı; Kür Nehri kıyısında, Hertvis'i; Ghodo kayasındaki Odzrhe'yi, Sper ve Çoruh Nehri kıyısındaki Tukharis'i ${ }^{21}$ ve birçok şehir gördü ardından ordusunu sağa sola ve yanlara sevk etti. Kendisi de Nastasis denilen yerdeki Ksan'a hücum etti. Mtkuris-Tzihe ve Tukharis'e gelince, kalelerin zapt edilmez olduğunu gören ìskender bu ismi geçen iki şehre hücum etmedi. Ancak diğer kaleleri altı ay içerisinde zapt etti. İskender, Kür Nehri ile Meskhta, Sarkine, Mtkuris-Tzihe, Kaheti ve Samswilde'yi içine alan sahada Bunturki ve Kıpçaklarla karşılaştı ve bu sırada Sarkine'de bulunan Bunturkiler ile mücadele etmek zorunda kaldı. Bunturkiler tarafından korunan Sarkine'yi bir yıl kadar kuşattıktan sonra Türkler gizli bir yolla şehri terk ederek Kafkasların yüksek kesimlerine çekildiler. İskender ise şehri ıssız bir şekilde teslim aldı. Ardından Makedonyalı, bütün Kartlosu zapt ederek halkını esir aldı ve bölgenin yönetimini akrabası Azon isimli şahsa bıraktı. ${ }^{22}$

iberia Bölgesi'ndeki ilk krallık sülalesi olan Parnavazi (Pharnabazus) veya Kartloslular’ın ilk hükümdarı Parnavaz (M.Ö. 302-237) Azon'a karşı isyan etti. ${ }^{23}$ Parnavaz ile eristav Azon arasındaki ilk mücadele, birçok Grekli süvarinin Parnavaz tarafina geçmesiyle başlamıştır. Azon, büyük sayıda askerinin iberialar'ın tarafına geçmesinden dolayı bulunduğu bölgede tutunamayarak Klarceti'ye çekilmiş ve müstahkem mevkilere kapanmıştır. Ardından Parnavaz, Azon üzerine yürüyerek Klarceti hariç bütün ỉberia'yı ele geçirdi. İki yıl Klarceti'nin müstahkem mevkilerinde kalan, Ardanuç kalesinde hazırlıklarını tamamlayan ve ordusunu toplayan Azon, Parnavaz'a karşı yürüdü. iki ordu Artan şehri yakınlarında yaptıkları kanlı bir savaş sonrasında Azon yenildi ve savaş meydanında öldü. Savaş sonrası Parnavaz, Klarceti ele geçirdi ve büyük bir sevinç yaşadı. Kartlı ve Egris Bölgesi'nin kralı olan Parnavaz, askeri gücünü ve hâkimiyetini kuvvetlendirdikten

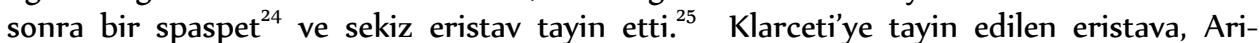
san'dan denize kadar uzanan yerleri verdi. Kendisi de ilkbaharda ve bağbozumunda başkenti Mtzheta'da, yazın ise Tsunda'da otururdu. Ara sıra Egris ve Klarceti'ye gider, Megreleri ile Klarçlari ${ }^{26}$ teftiş eder, aksaklıkları düzeltirdi. ${ }^{27}$ Parnavaz'dan sonra M.Ö. Il. yüzyılda Tao ve Gogarene (Gugarklı) ile birlikte Cholarzene (Klarceti), Strabon'dan öğrendiğimiz kadarıyla, Artaxias'ın (Ardaşes) (M.Ö.188-165) ${ }^{28}$ kuzeye seferi sırasında iberialılar'dan alındı ve Armenia monarşisine geçti. ${ }^{29}$ iberia Bölgesi'ne hakim durumdaki Parnavazi sülalesinin üçüncü kralı l.Mirvan'ın (159-109) ${ }^{30}$ döneminde Armenia Bölgesi'nde $^{31}$ Arsasid sülalesinin ${ }^{32}$ M.Ö. 149-127 seneleri arasındaki ilk kralı, İran'a hakim olan Büyük Arsas'ın (Mithidates 1. M.Ö.171 - 138) kardeşi Valarşak olmuştur. ${ }^{33}$ Büyük Arsas, Kalde'nin, Lazistan'ın, Pontus'un ve Aras'ın kuzeyindeki diğer memleketlerin kendi düşmanları olan Makedonyalılara sadık kaldıklarını görünce, bu memleketlerini kendisine karşı ayaklandıran Morfilik adlı birisine karşı harp etmiş, onu yenmiş ve diğer yerlerin arasında Klarceti, Odzrhe ve Egris ile birlikte birçok eristavlıklara sahip olmuştur. ${ }^{34}$

Mirvan'ın oğlu Farnajom (M.Ö. 112-93) döneminde, kralın İran ateşperestlik inancını kabul etmesi bölge halkı tarafından hoş karşılanmamıştı. Halk, Armenia Bölgesi'ne hakim - aslen bir Arsasid olan- Arşak'tan, krala karşı yapılacak bir darbeye destek vermesini talep etti. Yapılacak yardımın sonucunda Arşak'ın oğlunu iberia Bölgesi'nde kral 
olarak kabul edeceklerini bildirdiler. Bu tekliften sonra aldıkları yardım ile Kral Farnajom tahtan indirilmiş, yerine Armenia Bölgesi yönetici sınıfına mensup Arsasid Arşak (M.Ö. 93-81) tahta çıkmış ve bütün iberia'yı işgal ederek sakin bir saltanat sürmüştür. Arşak'tan sonra íberia tahtına oğlu Artag (M.Ö. 81-66) çıktı. ${ }^{35}$ Bu dönemde bütün şiddetiyle devam eden Roma-Mithradates savaşı iberia Bölgesini de etkiledi. İç ayaklanma ve kargaşalar nedeniyle gücünü epey kaybeden Romalılar, bu savaşın başında çok sıkıntılar yaşadılar. Ancak sonradan toparlanıp savaşın kaderini kendi çıkarları doğrultusunda değiştirmeyi başardılar. Roma İmparatorluğu'nun ünlü generali Pompeius, Krete, Kilikia ve diğer deniz meselelerini hallettikten sonra Pontus Kralı Mithradates ve Armenia Kralı Il. Tigranes'e (M.Ö.95-56) ${ }^{36}$ karşı yürümeye karar verip, ${ }^{37}$ ardından M.Ö. 66 ilkbaharında Pontus Kralı'na karşı sefere çıktı. Yapılan birçok savaşta yıpranan ve artık Pompeius'un kuvvetleri karşında duramayan Mithradates, uzun ve zorlu geçen bir yolculuktan sonra Kuzey Armenia dağ silsilesi boyunca ilerleyerek, M.Ö. 66 yılının son baharında Khorzene (Cholarzane-Klarceti) yöresinden geçip Armenia'ya girdi. Kolkhis'e varmak için; aşılması gereken kalın kar tabakalarıyla kaplı yüksek dağlar, sarp ve engebeli uçurumlar, ormanlık ve yolsuz dağ patikaları vardı. Ancak Mithradates, Kolkhis'e girişini engellemek isteyen Khorzene ve iberia süvarileri ile Absaros/Apsarros ırmağ ${ }^{38}$ kenarında karşılaştı. Yapılan çetin muharebeler sonunda Khorzene ve iberia askerlerini dağlara ve ovalara doğru kovup Kolkhis'e girdi. Ancak Mithradates'i takip eden Pompeius, Armenia kralı Il. Tigranes'i; ardından da M.Ö. 66/65 kışında konakladı̆̆ı Kur nehri kenarında Albania kralı Oroises'i girişilen üç ayrı savaşta yenerek kendisine tabi kıldı. Bu sırada Mithradates ile giriştiği savaşı kaybeden ve bir anlaşma halinde olan iberia kralı Artag, Pompeius'a elçiler yollayıp anlaşma teklif etti. Ancak bu teklifi kabul etmeyen Pompeius, M.Ö. 65 ilkbaharında Kur nehrini aşarak iberia topraklarına girdi ve Artag ile yapılan savaş sonrası 9000 iberia askerini öldürdü. Ardından aynı yılın ortalarına kadar iberia'yı yağmalayan Romalılar Artag ile anlaşma yaptı. 65 yılının yaz sonunda iberia seferini tamamlayan Pompeius, Pontos İmparatorluğu'na bağlı son vasallık olan Kolkhis'i de istila etti. $^{39}$

Artag'dan sonra oğlu Bartom (M.Ö. 66-33) iberia tahtına geçti. Fakat Arsasidler'in iberia bölgesinde 93 yılında başlayan hakimiyetleri Farnajom'un oğlu Il. Mirvan'ın (M.Ö. 33-22) başa geçmesiyle son buldu. ${ }^{40}$ ilk yüzyıldaki Armenia hükümdarlı̆̆ zayıfladığı esnada, Cholarzene (Klarceti), yeniden iberianların politik sahasına dönüştü. ${ }^{41}$ iberia tarihsel kaynakları, iberia'nın Kralı Il. Amzasp'a (M.S.182-186) karşı bazı diğer dükler ile Cholarzene dükünün, Armenia kralı ile anlaşarak düzenledikleri isyana kadar bu toprakların (Cholarzene) ilk yüzyılda Aderk (M.Ö. 2- M.S.55) ve Azork ( M.S.87-103) isimli iki kralın kontrolü altında olduğunu ifade eder. Hatta yine aynı kaynaklar Kral Azork'un aznavurlarından biri olan Klarceti eristavının, Tao'da bulunan Parhal memleketinde Armenia hududunu hiç rahat bırakmadığını; bölgenin ormanlar ve kayalarla çevrili olduğunu ve Klaceti'nin savaşçı bir halk tarafından müdafaa edildiği için hiçbir düşmanın buraya giremediğini iletmektedir. ${ }^{42}$

Kral Il. Amzasp döneminde Egris'den iki, Ordzhe, Klarceti ve Trunda'dan birer eristavın iştirak ettiği beş kişilik eristav ittifakı oluşturulmuştu. Bu müttefik güçler, Armenia kralı Ill. Dikran (151-193) ile anlaşarak düzenledikleri isyan sonucunda iberia kralını 
öldürüp, yerine Armenia kralının oğlu Rev'i (186-213) tahta çıkardılar. ${ }^{43}$ Bu olay, hiç şüphesiz ikinci yüzyılın sonuna doğru yeniden ortaya çıkan Arsasidlerin ikinci Armenia hükümdarlığı zamanında iberia-Armenia sınır bölgesini tersine çevirdi. Bölgede üçüncü yüzyılın ortalarına kadar Arsasidlerin hakimiyeti devam etti. Bu hakimiyet, Sasani Kralı Kisra'nın (1 Şaphur) Armenia ve iberia bölgelerine seferi ve iberia Kralı Asfagur'un (262-265) öldürülmesinden sonra yerine geçen Hüsrev hanedanlı̆̆ına mensup Mirian' in (265-342) iberia kralı olana kadar sürdü. ${ }^{44}$ Bu geri dönüşten sırasında, diğer bölgeler ve Arsasidler tarafindan şekillendirilen kuzey civarları yani Gogarene ve Vitaxate'yi ${ }^{45}$ kapsayan bölgeler ile Cholarzene de Armenia sınırları içerisindeydi. Bu dahil edilme Ananias tarafindan Cholarzene, Gogarene'nin bir bölümü olarak gösterilmesinin bir nedenidir. En erken Armenian literatüründeki ifadelere ek olarak Gregorian dokümanlarında da bir Armenian sınır vilayeti olarak Cholarzene'nin geçit bilinmektedir. ${ }^{46}$

IV.yüzyıl içerisinde İranlılar, ısrarla Kafkasya topraklarına doğru yayılmaya çalışıyorlardı. Buna karşın Romalılar doğuda giderek güç kaybettikleri için İran yayılmacılığına engel olamıyorlardı. ${ }^{47} 363$ yılındaki Roma-Pers Antlaşması, ${ }^{48}$ Kafkasya hükümdarlığının egemenlik haklarını İran'a teslim ederek Armenia'daki Arsasid Hükümdarlığı'nın sonunun gelmesine neden oldu. Arsasid Hükümdarlı̆̆ı' nın ortadan kalkması ile uzak bölgelerdeki sülalelerin bu hükümdarlığı terk etmesi aynı zamana denk gelmektedir. Bu nedenle ilk önce kuzeydeki Vitaxate ve ardında da Cholarzene tekrardan iberia hakimiyetine geçti. Ayrılıkçıların bazıları, 37ı'de orijinal bağlılıklarına geri dönmeleri için zorlanmalarına rağmen, 387'de Armenia Bölümünü terk ettiler. ${ }^{49}$

36ı'de Armenia kralı ile Hüsrevli Hanedanlığı' nın kurucusu ve ilk Hıristiyan Kral IIl. St. Mirian ${ }^{50}$ soyundan olan iberian Kralı Bakar (342-364) arasındaki anlaşmazlığa referans olan Leonati Mroveli tarafından yapılan kayıtta iberia tarihsel geleneklerinin yankılarını bulmamız mümkündür. Ayrıca aynı kaynaktan Bakar'ın halefi Ill. Mithridates'in (Mirdat 364-379) büyük bir dindarlık ile hükümdarlı̆̆ını yönettiğini; kilise bulunmayan Klarceti vadisinde (Cholarzen) ve Tukharis'te kiliseler inşa ettirdiğini ve bölgenin idaresi için papazlar görevlendirdiğini öğreniyoruz. ${ }^{51}$

Ammianus Marcelliunus'un verdiği bilgelere göre, Roma vasalı olan iberia kralı Sauromaces, İran Kralı Şapur tarafindan 368 senesinde hakim olduğu bölgelerden kovulmuş, yerine kuzeni Aspacures (Vazar Bakar) yerleştirilmişti. 363 Anlaşmasının bir sonucu olarak, İmparator Flavius lulius Valens (364-378), iberia hükümdarlığına Sauromaces'u yerleştirmek ve Kafkasya'da Roma etkisini restore etmek için Kont Arente'yi ve 12 lejyonun başında Terans'ı bölgeye sevk etti. Sauromaces, Kur nehri yakınlarına kadar ilerleyince Aspacures, iki kuzene yakışır bir biçimde krallığı aralarında paylaşmayı teklif etti. Bu anlaşmaya göre, krallığın güneybatı bölümüne yani Armenia ve Lazistan'a Roma vasalı Sauromaces hakim olurken İran vasalı olarak Aspacures de kuzeydoğusuna yani Albanya'nın hakimi olacaktı. Bu şekilde bölge Kur nehri boyunca iki kuzen arasında bölündü. ${ }^{52}$ Vazar Bakar döneminde İran kralı, Armenia ve iberia bölgesini vergiye bağlamak için büyük bir ordu ile bir eristavını sevk etti. Armenia yöneticileri Vazar Bakar’a ittifak teklif etmelerine rağmen, iberia kralı ülkedeki kale ve müstahkem mevkileri güçlendirerek savunma hattı oluşturmaya çalıştı. Ancak Iranlılar ilk önce Armenia Bölgesi' ne girerek büyük bir tahribat yaptıktan sonra yönlerini iberia Bölgesi' ne çevirdiler. 
Korkuya kapılan Vazar Bakar karşılık bile veremeyerek, Ran ve Movakan'ı İranlılara terk ederek vergi vermeyi kabul etti. Bu olaydan sonra, Vazar Bakar’a karşı isyan eden Klarçlar, Romalılar ile birleşerek Tukharisi ve denizden Arsian'a kadar Klarceti'nin tamamını zapt ettiler. Krala, yalnızca Klarceti hariç olmak üzere, Herat ve Egris ile Kartlı kaldı. Bu olay ile Romalılar Klarceti'yi, Vazar Bakar'ın elinden almış oldular. ${ }^{53}$

Leonati Mroveli'nin aktardıklarına göre, V. Yüzyılın başlarında Cholarzene'yi (Klarceti) kurtarmak için iberia kralı IV. Mithridates (408-410) Romalılardan, iberia'nın bir eyaleti olan Cholarzene'yi istedi. Ancak beyhude uğraşlar, bölgenin Vakhtang 1 . Gorgasal (446-522) ${ }^{54}$ dönemine kadar krallıktan ayrı kalmasını engelleyemedi. Vakhtang l. Gorgasal, İran ile savaş yıllarında (482-485), Roma İmparatoru Flavius Zeno'nun (474-491) kızı Helena ile evlenerek Roma ile müttefik oldu. Bu evlilik ile Vakhtang I. Gorgasal'ın politik yönünde bir değişiklik meydana geldi. Buna ek olarak İran ile yollarını ayırdı ve kendi yandaşlarını Roma İmparatorluğu'na transfer etti. ${ }^{55}$ İmparator bu evlilik sonucunda Vakhtang 1. Gorgasal'a, iberia topraklarını, Tukharis Kalesini, Arsian'a kadar Klarceti'nin bütününü ve Ghoda Dağı' na kadar uzanan vadileri iade etti. Böylece Kral 1 . Gorgasal , Vazar Bakar döneminden beri Roma bölgesine dahil olan Klarceti'yi yeniden iberia topraklarına kattı (378-482/488). Kral Gorgasal, İmparatordan bu bölgeleri çeyiz olarak alıp Klarceti yolu ile hareket etti ve ordusunu Armenia istikametine sevk etti. Tukharis'e varınca, ilk bakışta kaleyi çok beğendi ve : “Sen hakiki bir kalesin" dedi. Yolu üzerinde Klarceti'nin kıyılarında Artanuc (Ardanuç) denilen yere uğrayan kral, sütkardeşi Artvaz'ı oraya eristav olarak tayin etti. Bunun yanında süt kardeşine kaleyi tamir etmesini ; bir manastır, bir kilise ve Roma memleketinde gördügü şekilde bir rahibe manastırı yaptırmasını fakat vadiye zarar vermemesini tembih etti. Kral, aynı zamanda: "Iranlılar bize galip geldikleri takdirde burası sığınă̆ımız olacaktır" dedi. Nitekim Artvaz, orada Ardanuç kalesini, üç kilise ile Mere, Şindoba ve Akhiz kasabalarını inşa etti. ${ }^{56}$

Vl. yüzyılda Kafkasya, Bizans İmparatorluğu ve İran arasında bölünmüş bulunmaktaydı. Armenia'nın büyük bir bölümü (Persarmenia) ve Aşağı (Doğu) íberia'nın tamamı 526-532 Savaşları'ndan sonra İran hâkimiyetindeyken, Armenia'nın kalan bölümü ve Yukarı (Batı) iberia, Romanların elindeydi. ${ }^{57}$ Sasaniler döneminde iberia monarşisi, iç kavgalar ve Bizans ile İran'ın Kafkasya üzerindeki egemenlik kurma mücadeleleri sonucunda zayıfladı. iberia Kralı Gorgasal'ın ölümünün ardından bu zayıflama öyle bir hal aldı ki Sasani Kralı Hüsrev Anuşirvan (531579), iberia monarşisini lağvederek, iberia'nın iç işlerine doğrudan müdahale etmeye

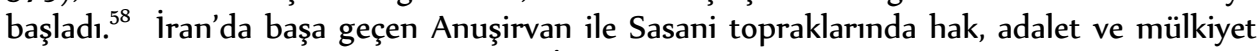
konularında normal bir nizam gelişti. İran'da Anuşirvan, büyük bir devlet adamı olarak belirmeye başladıkça Sasani Devleti'nin bölgedeki etkinliği arttı. Hatta 540 yılında İran valisi Tiflis'te yaşıyordu ve Tiflis bölgesi direk İran tarafından yönetiliyordu. iberia'daki son Hüsrevli olarak bilinen Farsman'ın oğlu Bakur'un (557-570) ölümünün ardından İran kralı Hüsrev Anuşirvan, Ran ve Movakan'ı oğlu Kisra Ambarvez'e verdi ve adı geçen prens Berza'ya yerleşti. Ardından iberia eristavları ile anlaşarak onların mülkiyet haklarını ırsi olarak tanıyacağını taahhüt etti. Buna göre, eristavlar bağımsızlıklarını ilan etmelerine rağmen Kisra Ambarvez'a vergi vermeye devam ettiler. Bu sırada Bakur'un 
oğulları kendilerini Kahet'in dağlık kısımlarında; Vahtang'ın oğlu Mirdat'ın Klarceti ve Javakethi sahipleri olan oğulları da Klarceti kayalıkları içinde kendilerini muhafaza ediyorlardı. Ancak 572'de başlayan İran karşıtı isyan hem íberia da hemde Armenia da patlak verdi. ${ }^{59}$ Gorgasal ve eşi Bizanslı Helena'nın torunları, Klarceti-Javakethi yöneticisi Guaram, Il. Vartan Mamigonyan ve Romalı müttefiklerinin İran kontrolünü kırmak için giriştikleri isyanda onların yanında yer aldı. Ancak 575'de İran, Roma ile savaşmalarına rağmen Kafkasya'da kontrolü sağladı. ${ }^{60}$

iberia'nın diğer bölümleri ile Armenia ve Vaspurakan, Bizanslılar ile harp halinde olan İranlıların elindeydi. II. lustinus'den (565-578) ${ }^{61}$ haleflerine miras kalan İran savaşları, Il. Tiberius'dan sonra enerjisi ve cesaretiyle dikkat çeken İmparator Maurikius'un $(582-602)^{62} 582$ yılında başa geçmesi ile yeni bir evreye girdi. Sasani Devleti'nin tahtında ise Hüsrev Anuşirvan'ın oğlu ve halefi IV. Hürmüz (579-590) bulunmaktaydı. IV. Hürmüz'ün sıkı finansal önlemleri, yüksek vergileri ve şiddetli din politikası ile Mazdaizm, Iberia soylularının İran'dan uzaklaşmasına sebep oldu. Maurikius'un kazandığı savaşlar ve Türklerin doğudan İran'a girmesi ile Mezopotamya taraflarında harp etmekte olan Bizanslıların İranlıları kovarak İran'a girip bölgeyi talan etmeye başlamaları, İran'da büyük kargaşalar çıkmasına neden oldu. Bu sebeplerden ötürü Hürmüz'ün oğlu KisraAmbarvez, íberia'yı ve Ran'ı terk ederek babasına yardıma gitti. İranlılar, iç kargaşaları ile meşgul oldukları sırada, yukarı ve aşağı eyaletlerin iberia eristavları ilk önce Sasani kontrolünden ayrılarak, 588'de Bizans İmparatoru Maurikius'a sadakatlerini bildirdiler. Ardından İmparator'a bir elçi göndererek eristavlıkların kendi eyaletlerinde kalması şartıyla, krallarının soyundan olan birisinin kendilerine kral tayin edilmesini ve iberia monarşisinin yeniden restore edilmesini rica ettiler. İmparator, Mirat'ın annesi tarafindan imparatorluk soyundan olan; o sırada güneybatıdaki Klarceti ve Javakheti'de yönetici olarak bulunan Guaram' 1 kral tayin ederek kendisine Küropolates unvanı verdi. ${ }^{63}$ Bagratlı Hanedanlığı'nın bölgedeki hâkimiyetini sağlayan Küropolates Guaram 575-600 yılları arasında bölgeyi yönetti ve bundan sonra iberia yönetici sınıfı Guaramidler olarak anılmaya başladı. ${ }^{64}$

Bu zaman diliminde iki büyük gücün bölgede yaptıkları mücadelelerde Bizanslıların üstünlüğü göze çarpmaktadır. Ancak bu duruma neden olan sebepler arasında Sasani Devletinin içinde bulunduğu iç karışıklıklar ve Sasani Komutanı Vahram Çoben/Behrem Çubin'in isyanı önemli bir yer tutmaktadır. Vahram Çoben, Bizans sınırında giriştiği birkaç savaştan yenik ayrılmış, bunun üzerine Kral IV. Hürmüz' ün çok sert tepkisiyle karşılaşmıştır. Bu tepkiyi bahane ederek krala karşı ayaklanan Vahram Çoben, tahtta hak iddia etmiş ve Hürmüz'ü devirerek 590 yılında tahta çıkmıştır. ${ }^{65}$

Bizans, Doğu sınırında bu firsattan istifade edebilmek için harekâta geçti ve ordularından bir tanesini Pers Armeniasi olarak tabir edilen bölgeye gönderdi. Bu ordu Divin’i muhasara ederken, Sasani Hükümdarlığı için mücadele iyiden iyiye alevlenmiş; Hürmüz ülkesini terk ederek Bizans'a sığınmıştı. İmparator'dan kendisine yardım etmesini isteyen Hürmüz, yeniden tahta çıktığı takdirde Kuzey Mezopotamya'yı Nisibis'e kadar; Basean, Vanand, Şirak, Arakadzodin'in içersisinde bulunduğu Divin'i, Ararat'a ve Van Gölü'ne kadar olan bölgeyi tüm bunlarla birlikte Tiflis'e kadar iberia'nın bir kısmını vereceğine söz verdi. ${ }^{66}$ Bu teklifi kabul eden İmparator Maurikius, Hüsrev'i himayesi altına alarak, 
onu İran tahtına oturtmaya hazırlandı. Bu arada yapılan bu ittifaka karşı bir hamle olarak Vahram Çoben, Ermeni Nakharlarına birleşme teklifinde bulundu. Ancak bu teklif Ermeni ileri gelenleri arasında pek taraftar bulamadı. Ermeni birlikleri ve Patricius íoannes'in komutasında olan Bizans birlikleri, Hüsrev Pervez'in sancağı altında bulunan Sasani birliklerine katıldılar. Güç birliği etmiş olan bu birlikler, Vahram Çoben ile Udya Eyaleti'nde bulunan Kantzag'da karşılaştılar (590). Bu muharebe müttefiklerin kesin zaferiyle sonuçlandı. ${ }^{67}$ Yenilen Vahram Çoben, Türklerin yanına -Belh'e- kaçtı ve GökTürklere sığındı. ${ }^{68}$

Bizans yardımı ile tahtını geri alan Hüsrev Perviz, vaat ettiği bütün taahhütleri yerine getirdi. Bu muahede ile Tiflis şehrine kadar iberia'nın büyük bir kısmı, Ararat'ın batısında bulunan Basean Bölgesi, Arakadzodin ile Vanand (Kars), Şirak (Şüregel) Bölgeleri ve Maku'ya kadar Van Gölü'nün kuzeydoğusu Bizans'in hâkimiyetine geçti. ${ }^{69}$ 59l'deki taksim anlaşmasından sonra İmparator Maurikius elindeki Armenia Eyaletleri'nde ve bunlara komşu olan Kapadokya ve Pontus Bölgeleri'nde yeni bir idari dağılım yaptı. Sasanilerin bıraktığı kazalara gelince; Bizanslılar, Deveboynu'ndan Gökçegöl'e (Sevan) değin uzayan Aras boyundaki yeni alınan yerleri i̇ç Armenia ve Aşağı Armenia diye iki bölüme ayırdı. Erzurum/Kars ve Klarceti'nin de içerisinde bulunduğu Çoruh vadisinden Aras vadisine kadar $\mathrm{i}_{c ̧}$ Armenia; buraların doğusundaki Kars-Gökçegöl arasında ve Aras Nehri'nden Kür Irmağı'na kadar uzayan yerlere de Aşağı Armenia adını verdiler. Böylece 591 yılında Sasani tahtına Hüsrev'in geçmesi ile 20 yıldır süre gelen savaş sonra ermiş; Bizanslılar ilk defa Vanand ili'ne kadar hâkim olmuş; bu bölgeler 604' te yeniden Sasani-Bizans savaşları başlayıncaya kadar Bizans idaresine bağlı kalmıştır. $^{70}$

Bizans-Sasani mücadelesinin bütün hızlıyla devam ettiği bu dönemde iberia bölgesinde yönetici olarak bulanan Küropolates Guaram, 600 yılında yaşamını yitirdikten sonra oğlu Stefanos (600-619) başa geçti. ${ }^{71}$ iberia'da Stefanos hakimiyeti sürdüğü dönemde, Bizans'ın içerisinde bulunduğu buhran sonucu İmparator Maurikius'u devirip idam eden Phokas, tahta geçti (602-610). ${ }^{72}$ Sasani Kralı Hüsrev, imparatorluk merkezindeki olayları bahane ederek, Phokas'dan intikamını almak ve bir minnettarlık karşılı̆̆ olarak Bizans'a verdiği yerleri geri almak için yaklaşık yirmi beş yıl sürecek (604-629) olan savaşı başlattı. ${ }^{73} 610$ yılında imparatorluk merkezinde meydana gelen karışıklıktan yararlanan Heraclius (610-641), Bizans tahtına oturdu. ${ }^{74}$ Sasani Kralı Hüsrev'in 22. yılında Bizans İmparatoru olan Heraclius, ilk iş olarak Hüsrev ile bir anlaşma yapmak isteyip bu amaca ulaşmak için görkemli hediyeler ile elçilerini Hüsrev'e gönderdi; ancak Hüsrev buna kesin bir dille karşı çıtı. ${ }^{75}$ İmparator Heraclius, Paskalya'nın ikinci günü, 5 Nisan 622 tarihinde dinsel bir törenden sonra ìstanbul'u terk ederek Anadolu'ya geçti; asker topladı ve Sasani komutanı Şahvaras (Şahrbaraz) ile Kayseri Bölgesi'nde bir savaş yaptıktan sonra İstanbul'a geri döndü. ${ }^{76} 623$ yılında gemilerle Trabzon'a geçen İmparator, Bayburt yolu ile Theodosiopolis'e geldi ve daha sonra Basean- Vanand yolu ile Divin üzerine yürüdü. Oradan Nahcivan'a kadar giden İmparator, Gence'de Hüsrev ile giriştiği savaşı kazanarak Gence'yi aldı ve kışı geçirmek üzere Aras Nehri'nin doğusuna çekildi. ${ }^{77}$ Sasaniler ile savaş 627 yılına kadar devam etti. Hüsrev'in öldürülmesinden sonra yerine geçen oğlu Kavad-Şeroe (Şiruye) ile Heraclius arasında yapılan anlaşma sonucunda 
İranlıların aldıkları bütün yerler Bizans'a teslim edildi ve böylece savaş sonra ermiş oldu. $^{78}$

Gürcü kaynaklarına göre bu olaylar yaşanırken Mtavari Stefenos, Tiflis'te oturup İranlılara itaat ederdi. Stefanos, İmparator Heraclius'un doğu seferi sırasında İranlılara karşı isyan etmek istemedi; ayrıca Bizanslılara karşı mukavemet gösterebilmek için şehirlerini ve kalelerini tahkim etti. ${ }^{79}$ Ancak imparator, Tiflis'e gelerek şehri kuşattı ve süren kuşatma sırasında Stefanos öldü. Ardından şehir İmparator Heraclius' un eline geçti. İmparator, Vahtang'ın soyundan gelen ve iberia kralı Bakur'un oğlu Kakheti eristavı Adarnase'ye (619-639, 627-637) Tiflis'i verdi ve kendisini iberia mtavarı ilan etti. İmparator Heraclius, kendisine tabi olmak istemeyen şehrin iç-kalesinde kalmış olan kuvvet komutanının tahriklerine aldırış etmeden, kuşatmayı sürdürmesi için Cibga (CibguCebu-Jebu $)^{80}$ isimli eristavını iç kalede bıraktı. Mtavari Adarnase ile eristav Cibga birkaç gün içerisinde kaleyi zapt ettikten sonra kale komutanını öldürüp imparatora gönderdiler. Bundan sonra Bizanslılar, iberia topraklarından İspir'i ve Klarceti Bölgesi ile sahil kısmını zapt ettiler. Stefanos'un oğulları Klarceti'nin kayalık yerlerinde kaldılar. Mtavar Adarnase, iberia'nın diğer kısımlarını zapt etti ise de kral unvanını almağa cesaret etmedi. Eristavlar ise Adarnase'yi metbu tanıyarak kendi topraklarına ırsi hakla sahip kaldılar. $^{81}$

iberia Bölgesi'ne VIl. yüzyılın ortalarına kadar Bizans hâkimiyeti mevcut iken Arap yarımadasından İslâm ordularının Kafkasya'ya yönelik ilk harekâtı Hz. Ömer devrinde başladı. Sürâka b. Amr, 22'de (643) Bâbülebvâb Kralı Şehr-Berâz ile barış yaptıktan sonra Habîb b. Mesleme ileri harekâta devam ederek bazı yerleri ele geçirdi. Habîb b. Mesleme daha sonra Hz. Osman zamanında İrmîniye'nin (Armenia) fethiyle görevlendirildi. Duvîn'i zapteden Habîb, Gürcistan'ın merkezi Tiflis üzerine yürüdü ve şehri fethedip Gürcüler ile bir anlaşma yaptı (25/645-46). Buna göre halkın canına, mabetlerine, kiliselerine ve havralarına dokunulmayacak; onlar da her aile için 1 dinar cizye ödeyecek; Müslümanlarla dost olacak; Allah ve Resulü'nün düşmanlarına karşı düşmanlık edeceklerdi. Belazuri, İslam akınlarını anlatırken Habib'in Cevahir, Kesferbis, Kisal, Hunan, Semsehi el-Cerdam, Küstesci Bazelti ve Şevşeti sulh yulu ile fethettiğini ve Kalercit (Klarceti) halkları ile anlaştığını bildirmektedir. ${ }^{82}$

Sonuç olarak Urartu kayıtları ile tarih sahnesine çıkan Artvin'in tarihi ve sosyokültürel yapısı, Kafkaslardan gelen iki ayrı büyük göç dalgası ile değişmiş ve ilk göç harekâtı ile bölgeye ulaşan Kimmerler kısa süreli bir hakimiyet sergilemişlerdir. Ancak Urartuların kuzeyde güç kaybetmesi üzerine varlıklarını ve güçlerini hissettirmeye başlayan ayrıca bölgede şu anda bile yaşamakta olan bir çok yere isimlerini veren ìskitler, yaklaşık Il asır bölgede hakimiyet sürmüşler; fakat V. yüzyılın ortasına doğru kendisini hissettiren Pers etkisi, Güney Kafkasya hakimiyetinde değişikliğe neden olmuştur. Büyük İskender'in bölgeye gelişi ile Kafkaslar, Helenizim ve Pers kültürünün mücadele merkezi haline dönüşmüş; ancak Azon isimli eristav bertaraf edilmiş ve ilk iberia menşeili sülale olan Parnavaz sülalesi bölgede hâkimiyet sağlamışlardır. Coğrafi olarak Armenia ve iberia sınır bölgesinde bulunan; Ptolemy tarafından bir Armenia Bölgesi olarak tanımlanan ve sık sık el değiştiren Klarceti Bölgesi, Roma İmparatorluğu'nun, Mithradates üzerine seferi sırasında General Pompeius tarafından iberia bölgesi ile Roma İmparator- 
luğu'na katılmıştır. ỉberia Bölgesi, uzun yıllar Roma vasalı olarak varlığını sürdürmüş; gerek Kartlı gerekse Arsasid Hanedanlığı' na mensup krallar tarafindan yönetilmiştir. IIl. yüzyılın sonlarına doğru iyice hızlanan Roma-İran savaşları 298 yılı Nisibis Barışı ile kısa da olsa bölgede huzurun sağlanmasına sebebiyet vermiş; Klarceti Bölgesinin de içerisinde bulunduğu Gogarane Bölgesi, Roma İmparatorluğu'nda kalmıştır. Ancak IV. yüzyılın ortalarına doğru yeniden alevlenen mücadele, 363 yılı joian Barışı ile son bulmuş; Gogarane Bölgesi, İran topraklarına katılmıştır. Bunu takip eden on yıl içerisinde bölgede hak iddia eden iki kuzen arasındaki mücadeleye Roma İmparatorluğu da müdahil olmuştur. Yapılan barış sonrası Vazar Bakar'ın hâkimiyet sahası olarak kabul edilen Klarceti Bölgesi' nde çıkan isyan sonucunda burada yaşayan halk, Roma İmparatorluğuna katılmak istemiştir. Bölge 378-482/488 yılları arasında Roma hâkimiyetinde kalmış; ancak Vakhtang 1 Gorgasal, Bizans İmparatorunun kızı ile evlenerek Klarceti'yi yeniden iberia topraklarına katmıştır. Sasani-Bizans arasındaki uzun mücadeleler sırasında birçok kez el değiştirmiş bir sınır bölgesi olarak bilinen Klarceti, Vıl. yüzyılın ortalarına doğru Habîb b. Mesleme yönetimindeki Arap akınlarına maruz kalmıştır. Bu akınlar, genel itibari ile fetih ve ganimet ağırlıklı olmasının yanında, daha sonraki yüzyıllarda Kafkasların iç bölgelerine doğru ilerleyecek olan Müslüman akınlarına zemin hazırlamış ve bölge halkı arasında İslamiyet'in yayılmasına büyük katkı sağlamıştır.

\section{KAYNAKÇA}

ADONTZ, Nicholas, Armenia in The Period of Juztinian, (trans. Nina G. Garsoian), Lisbon 1970.

AGATHANGELOS HISTORY OF THE ARMENIANS, (trans. and commen Robert W.Thomson), State University of New York Press 1976.

ALLEN, W.E.D., A History of The Georgian People, London 1932.

ARRiANUS'UN Karadeniz Seyahati: Arriani Periplus Ponti Euxini, (çev. Murat Arslan), Odin yay. istanbul 2005.

ARSLAN, Murat, Roma'nın Büyük Düşmanı Mithradates VI Eupator, Odin Yayıncılık, ìstanbul 2007.

BALA, Mirza, "Gürcistan", islam Ansiklopedisi, Cilt: IV, Milli Eğitim Basım Evi, İstanbul 1987, s. $837-845$.

BEDROSIAN, Robert, Georgian Chronicle Juansher's Concise History of the Georgians, New York 1991.

BELAZURi, Fütühu'l Büldan, (çev. Mustafa Fayda), Kültür Bakanlığı Yay., Ankara 2002.

BERDZENişVili, Nikoloz - CANAŞiA Simon, Gürcistan Tarihi (Başlangıçtan 19. Yüzyıla Kadar) (çev. Hayri Hayrioğlu), Sorun Yayınlar, İstanbul 2000.

BiSHOP John Mamikonean's History of Taron, Venice, 1889 (Yovhannu Mamikoneni episkoposi Patmut'iwn Taronoy), (çev. Robert Bedrosian), New York 1985.

BROSSET, Marie Félicité, Gürcistan Tarihi (Eski Çağlardan 1212 Yılında Kadar), (çev. Hrand D. Andreasyan, Not. ve Yay. Erdoğan Merçil), TTK Yay., Ankara 2003.

BURNEY, Charles - Lang David Marshall, The Peoples of The Hills (Ancient Ararat and Caucaus) London 1971.

CHAMiCH, Father Michael, History of Armenian, From B.C. 2247 to the of Christ 1780, or 1299 of the Armenia Era, (trans. Johannes Avdall), Calcuta 1827.

ÇiĞDEM, Süleyman, Urartu Kralliğı́nın Doğu Karadeniz ilişkilerinde Diauehi Ülkesinin Rolü, Atatürk Üniversitesi Sosyal Bilimler Enstitüsü Dergisi, Cilt 9, Sayı 1, Erzurum 2007.

DiAKONOF, lgor M. - S.M.Kaskai, Geographical Namse According to Urartian Texts, Wiesbaden 1981. 
EBŨ Cafer Muhammed Bin Cerir'üt- Taberi, Tarih-i Taberi, (neş. M.Faruk Gürtunca), Cilt: III, istanbul, Tarihsiz.

Ebülgazi Bahadır Han, Türklerin Soykütügüü, (neş. Muharrem Ergin).

EMiR, Osman, Prehistorik Dönemden Roma Dönemine Kadar Trabzon ve Çevresi, Serander Yay., Trabzon 2011.

ERZEN, Afif, Doğu Anadolu ve Urartular, TTK Yay., Ankara 1992.

GÖMEÇ, Sadettin, “ỉslam Öncesi Türk Tarihinin Kaynakları Üzerine”, Tarih Araştırmaları Dergisi, Yıl 1999-2000 sayı 31, Ayrı Basım, Ankara 2000.

GROUSSET, Rene, Başlangıcından 107ı'e Ermenilerin Tarihi, (çev. Sosi Dalanoğlu), ìstanbul 2005.

GUMiLEV, L.N. , Hazar Çevresinde Bin Yıl, (çev. Ahsen Batur) Selenge 2003.

HEREDOT Tarihi, (çev. Müntekim Ökmen), İş Bankası Yay., ìstanbul 2006.

HEWSEN, Robert H., Armenia A Historical Atlas, The University of Chicago Press, London 2001.

, The Gepgraphy of Ananias of Sirak (Asxarhac'oyc'), The Long and Short Recensions, Wiesbadan 1992.

HONiGMAN, Ernst, Bizans Devletinin Doğu Sınırı, (çev. Fikret lşııtan), ìstanbul 1970.

http://www.maproom.org/oo/26/present.php? $m=0004$

HÜBSCHMANN, Heinrich, Die Altarmenischen Ortsnamen, Amsterdam 1969.

IŞIK, Adem, Antik Kaynaklarda Karadeniz Bölgesi, TTK Yay. Ankara 2001.

iBNÜ'L- ESiR, El-Kâmil fi't-Tarih, Cilt 1lı, Bahar Yayınları.

ISAAC, Benjamin, The Limit of Empire ( The Roman Army in the East) Oxford 2000.

JENKiNS, Romilly, Byzantium, The Imperial Centuries A.d. 610-1071, New York: Random House 1966.

KAFKASYALl, Ali, iran Türkleri, Bilgeoğuz Yay., ìstanbul 2010.

KAEGi, Walter E., Bizans ve Ilk Islam Fetihleri, (çev. Mehmet Özay), ìstanbul 2000.

KIRZIOĞLU, M. Fahrettin, "Selçuklu Fetihlerinden Önce Doğu Anadolu Türk Boy ve Oymaklarından Kalma Dağ ve Su Adları", Türk Yer Adları Sempozyumu Bildirileri, 11-13 Eylül 1984 Ankara.

, Yukarı-Kür ve Çoruk Boyları'nda Kıpçaklar, TTK. Yay., Ankara 1992.

,Kars Tarihi, , ìstanbul 1953.

KiEPERT, Heinrich, A Manual of Ancient Geography, (trans., Ph. D)., Londra 1881.

KÖROĞLU, Kemalettin "Urartu Krallı̆ının Kuzeye Yayılımı ve Qulha Ülkesinin Tarihi Coğrafyasi", Belleten, Cilt:LXIV, TTK. Yay., Ankara 2000. s.717-747.

LANG, David Marshall, Eski Halk ve Ülkeler Gürcüler, (çev. Neşenur Domaniç), Ceylan Yay., istanbul 1997.

LEMERLE, Paul, Histoire de Byzance -Bizans Tarihi-, (çev. Galip Üstün), ìstanbul 2006.

MOSES KHORENATS'i History Of The Armenians, (trans. Robert W.Thomson), London 1980.

MOSES Kalankatli, Alban Tarihi ve Alban Salnamesi, ( Rusça ve İng.'den Azerbaycan Türkçesine Çeviri Ziya Bünyadov, Türkçe çev. Yusuf Gedikli), Selenge Yay., İstanbul 2006.

MOVSES Dasxurants'i'sHistory of the Aghuans, (translated from Classical Armenian by Robert Bedrosian), Book 2, B.12.

P'AWSTOS Buzandac'i's' History of the Armenians, (trans. Robert Bedrosian), New York 1985.

SAGONA, Antonio and SAGONA Claudia, Archaelogy at The North-East Anatolian Frontier l, An Historical Geography and a Field Surevt of the Bayburt Province, Paris 2004.

SAiNT-MARTiN M..., Memoires Historiques et Geographiques Sur L'Armenia, Paris 1818.

SANDALGiAN, Joseph, Histoire De L'Armenie, Roma 1917.

SEBEOS, Patmitiwn Sebeosi Episkoposi Herakin; Sebeos History, (trans. Robert Bedrosian), New York, 1985. 
SiHARULIDZE, Yuri-Alexandre Manvelişivli-J. Gogebaşvili-Tsate Batsaşi-ivane Canavhişvili-Biçi Tezelişvili-Mihako Tseretli- Mariam Lortkipanidze, Trabzon'dan Abhazya'ya Doğu Karadeniz Haklarının Tarihi ve Kültürü, (çev. Hayri Hayrioğlu), Sorun Yayınları, İstanbul 2005.

STRABON XI. 14. 4-5. (trans. W.Falconer), London, 1903,

http://rbedrosian.com/Classic/strabolld.htm 22.06. 2011 saat 12.48

SUBAŞl, Ömer, “Artvin ve Çevresinin Tarihi Coğrafyası”, Karadeniz Incelemeleri Dergisi, Sayı:12 Bahar 2012, Trabzon, s.9-25.

TAŞAĞlL, Ahmet, Gök-Türkler, TTK. Yay., c .l,1l,Ill, Ankara 2000.

TELlioĞLU, ibrahim, Osmanlı Hakimiyetine Kadar Doğu Karadeniz'de Türkler, Serander Yay., Trabzon 2007. XI-XIII. Yüzyıllarda Türk-Gürcü Ilişkileri, Serander Yay. Trabzon 2009.

"Prof. Dr. M. Fahrettin Kırzıoğlu'nun Karadeniz Türk Tarihi Araştırmalarına Katkıları", Türk Dünyası Araştırmaları, 2009/180 Mayıs-Haziran, s. 19-38.

The Roman History of Ammianus Marcellinus: During the Reigns of the Emperors Constantius, Julian, Jovianus, Valentinian and Valens, (trans .Charles Duke Yonge), 27.12-16-17, London 1894, http://www.archive.org/details/romanhistoryamm00marcgoog

THOMSON, Robert W., Rewritg Causcasian History, The Medieval Armenian Adaptation of the Georgian Chronicle, The Orginal Georgian Texts and The Armenian Adaptation, Oxford 1996.

The Armenian History Attributed to Sebeos, translated, with notes; Sebeos History, Liverpool 1999.

TOGAN, Zeki Velidi, Oğuz Destanı, Reşieddin Oğuznamesi Tercümesi ve Tahlili, i̇stanbul 1972.

TOGAN, Zeki Velidi, Umumi Türk Tarihine Giriş, Enderun Kitapevi,C.l. İstanbul 1981.

TOUMANOFF, Cyril, Studies in Christian Caucasian History, Washington, D.C., Georgetown University Press, 1963 pub. 1965.

, Armenia and Grorgia, The Cambridge Medieval History, vol IV. The Byzantine Empire part l, pp. 593-637, Cambridge 1966. Caucasia and Byzantium, The journal Traditio 27 (1971).

THE GEOGRAPHY BY CLAUDIUS PTOLEMY, (trans. and edt. by Edward Luther Stevenson) New York fi932, repr. 1991, 5. Kitap. B.12.

UMAR, Bilge, Türkiye'deki Tarihsel Adlar, İnkılap Yay., İzmir 1993.

, Karadeniz Kappadokia'si (Pontos), lstanbul 2000.

URAS, Esat, Tarihte Ermeniler ve Ermeni Meselesi, Belge Yayınları, ìstanbul, 1987.

VASiLiEV, A.A., Bizans Imparatorluğu Tarihi, (çev. Arif Müfid Mansel), Ankara 1943, c.l

WAKHOUCHT, Tsarevitch, Description Geographique de la Georgian, (trans. M. Brosset), S.Petersbourg 1842.

WiESEHÖFER, Josef, Antik Pers Tarihi (çev. Mehmet Ali İnci), ìstanbul 2003

1973 Artvin il Yıllı̆̆.

'Urartular hakkında geniş bilgi için bk. Afif Erzen, Doğu Anadolu ve Urartular, TTK Yay. Ankara 1992.

${ }^{2}$ Luşa: İşpuini ve Minua dönemi yazıtlarda Lušá-i-né-e-de ve Lu-ú-šá-a olarak, Argişti dönemi yazıtlarda ise Lu-šá-a-e olarak geçmekte ve Transkafkasya'nın güneyine lokalize edilmektedir. Witerhu: İşpuini ve Minua dönemi yazıtlarda, Ú-i-té-ru, Argişti dönemi yazıtlarda ise Ú-i-té-ruhi-né-i olarak geçmektedir. Bir kabile ve onların yaşadığı bölge olarak ta Kağızman yakınlarında Yukarı Aras havzasına lokalize edilmektedir. Katarza, İşpuini ve Minua dönemlerindeki yazıt- 
larda Ka-a-tar-za-a, Ka-tar-za-a, Ka-tar-za-ne-é-de olarak geçerken Argişti döneminde ise isim Ka-tar-za-a-e olarak geçmekte olup, Minua tarafindan Luşa ve Witerhu arasında olduğu söylenmekte ve Klarceti Bölgesine lokalize edilmektedir. Igor M.Diakonoff - S.M.Kashai, Geographical Names According to Urartian Texts, Wiesbaden 1981, p.48, 52, 102.

${ }^{3}$ iş̧ tepe, Kasımoğlu Steli ve Toprakkele yazıtlarıdır. bk. Kemalettin Köroğlu, Urartu Krallığını Kuzeye Yayılımı ve Qulha Ülkesinin Tarihi Coğrafyası, TTK Yay., Belleten, c.LXIV, Ankara 2000, s.718, 728.

${ }^{4} A$ rgişti'nin ikinci yılında, Babası Minua'nın yaptığı gibi Diauehi ülkesine karşı sefere çıktığı sırada devletin kurulduğu dönemden beri denetim altına alınamayan Luşa, Witeruhe ve Katarza'yı yağmalamıştır. Argişti, hakimiyetinin on üçüncü yılında Aras vadisine kadar gelerek bölgeye yerleşmiş ve daha kuzeye yönelerek Etiuhe, Wireruhe ve Katarza'yı almıştır. bk. Köroğlu, Urartu Krallığının Kuzeye Yayılımı ve Qulha Ülkesinin Tarihi Coğrafyası, s.717, 724, 726 dip not 44.

${ }^{5}$ Urartu dokümanlarına göre Diauehi Bölgesinin (Asur kaynaklarınca Daiaeni (Daiani) konfederasyonu adı verilen bölgeye, Urartu dilinde Diauehi (Diaohi), Yunan kaynaklarında ise Taokhoi'ler (Taokh'lar) olarak adlandırılıyordu. bk. Ksenophon, Anabasis (Onbinlerin Dönüşü), (çev. Tanju Gökçöl), İstabul 1998, s.132-140; David Marshall Lang, Eski Halk ve Ülkeler, Gürcüler, (çev. Neşenur Domaniç), Ceylan Yay., İstanbul 1997, s.52; Melikishvili, Diauehi Ülkesini Yukarı Fırat ve Erzurum ve çevresiyle Güneybatı Gürcistan arasına, Diakonoff-Kashai, Çoruh Havzası ile Fırat ırmağının kaynak kesimlerinin arasındaki bölgeye, Rusell, Erzurum-Erzincan ovalarından Doğu Karadeniz dağlarının eteklerine kadar uzanan bölgeye, Herzfeld, Çoruh Kaynak bölgesindeki Oltu ve civarına, Pehlivan ise Sarıkamış'la Aşkale arasındaki bölgeye lokalize etmiştir. Süleyman Çiğdem, Urartu Krallığı'nın Doğu Karadeniz ilişkilerinde Diauehi Ülkesinin Rolü, Atatürk Üniversitesi Sosyal Bilimler Enstitüsü Dergisi, Cilt 9, Sayı 1, Erzurum 2007, s.96-97; Osman Emir, Prehistorik Dönemden Roma Dönemine Kadar Trabzon ve Çevresi, Serander Yay., Trabzon 2011, s.64.

${ }^{6}$ Diakonoff -Kashai, Geographical Namse According to Urartian Texts, p.48,49.

${ }^{7}$ Anadolu'nun kuzey-doğusunda, kuzeyinde -iskitlerce karbeyaz anlamına gelen- Kaukasus Dağları, güneyinde Armneia, doğusu iberia ve batısı Pontus Euxeinos (Helen dilinde Deniz anlamında ve Pontos Euxenios Helen dilinde "Yabancılara dost deniz" anlamına gelmektedir) tarafindan çevrilmiş bir bölgedir. Geo. Egri veya Egrisi; Arm. Eger Urartu kayıtlarında geçen Qulha bölgesine tekabül etmektedir. Klasik kaynaklarda Eger ismi görünmesine rağmen Roma ve Grekler tarafından bu bölgeye Kolkhis/Colkchis denmiştir. Halkına Kolkhisliler denir. Köken olarak Mısırlıdırlar. Mısır kralı Sesostris çıktığı seferinde bu bölgelere kadar gelmiş, işte bu Kolkhisliler Mısır ordunsun arada kalanlarıdır. Kolkhis Bölgesi elverişli iklimi, bol madenleri ve tabiat güzellikleriyle Yunan aleminde daima bir düş ve zenginlik ülkesi olarak kabul edildi. Miletoslular, kolonizasyon hareketleri esnasında bu bölgede Dioskurias ve Phasis gibi şehirleri kurarak buralarda yerleşmişler ve bölge de ilk Yunan kolonizasyonlarının temellerini atmışlardır. Ayrıca antikçağda Kolkhis Bölgesi'nin ünlenmesi Argonaut'lar (Argo Gemiciler) ve Altın Post efsanesi sayesinde olmuştur. bk. Heredot Tarihi, (çev. Müntekim Ökmen), iş̧ Bankası Yay., isstanbul 2006, s.164-165; Strabon XI. II. 17, (çev. W. Falconer), London 1903, p.227; Robert H. Hewsen, The Geography of Ananias of Sirak (Asxarhac'oyc'), The Long and Short Recensions, Wiesbadan 1992, p.125; Arrianus'un Karadeniz Seyahati, (Arriani Periplus Ponti Euxini), (çev. Murat Arslan), Odin Yay., İstanbul 2005, s.60,61; Ksenophon, Anabasis, s. 140; Heinrich Kiepert, A Manual of Ancient Geography, (trans. Ph. D), Londra 1881, p. 54-55; Nicholas Adontz, Armenia in The Period of Juztinian, (trans. Nina G. Garsoian), Lisbon 1970, p. 154; Bilge Umar, 
Türkiye'deki Tarihsel Adlar, İnkılap Yay., İzmir 1993, s.673; Adem lşık, Antik Kaynaklarda Karadeniz Bölgesi, TTK Yay., Ankara 2001, s.14,15- 205,210., Joseph Sandalgian, Histoire De L'Armenie, Roma 1917, p. 39; Benjamin Isaac, The Limit of Empire ( The Roman Army in the East), Oxford 2000, p.9,10.

${ }^{8}$ Yuri Siharulidze-Alexandre Manvelişivli- J. Gogebaşvili-Tsate Batsaşi-ivane Canavhişvili-Biçi Tezelişvili-Mihako Tseretli-Mariam Lortkipanidze, Trabzon'dan Abhazya'ya Doğu Karadeniz Haklarının Tarihi ve Kültürü, (çev. Hayri Hayrioğlu), Sorun Yayınları, İstanbul 2005, s.43.

${ }^{9}$ M.Ö. XIIl. Yüzyıldan sonra çeşitli kollar halinde yaklaşık beşyüz yıl Kafkasya, Kırım ve Dinyeper havzasına yayılan Kimmerler, M.Ö. VIII. yüzyıl ile M.Ö. 500 arasındaki dönemde iskit akınları sebebi ile güneye ve batıya çekilerek muhtelif memleketlere göç etmişlerdir. ibrahim Tellioğlu, Osmanlı Hakimiyetine Kadar Doğu Karadeniz'de Türkler, Serander Yay., Trabzon 2007, s.18,19;

${ }^{10}$ Sakasen ismi Ptolemy'de Sacapane olarak geçmektedir. bk. The Geography by Claudius Ptolemy (trans. and edited by Edward Luther Stevenson) New York 1932, repr. 1991, 5. Kitap. B.12, p. 124; Sakasen isminin farklı yazım şekilleri ve okunuşu hakkında bk. Robert H.Hewsen, Armenia A Historical Atlas, The University of Chicago Press, Chicago 2001, p.64.

"Asur kitabelerinde i̇skit kralının adı olarak yazılan Gogu yahut Gog'un, Gogar demek olduğu, bununda Türkçe bir kelime Gök ve Göker demek olduğu, M.Ö. 665'te Kür ırmağını geçen Sakaların elde ettikleri bu bölgelerin de yukarıdaki isme izafeten Gogaren olarak anıldığı düşünülmekte ve Sakasen ismi de, Saka sözünün Şehir ve Türbe manasına ifade eden Türkçe 'sin' kelimesiyle birleştirilmesinden ibaret olduğu iddia edilmektedir. Zeki Velidi Togan, Umumi Türk Tarihine Giriş, Enderun Kitapevi, C.1. İstanbul 1981, s.166; Sandalgian, Histoire De L'Armenie, p. 253, 364-365; ibrahim Tellioğlu, XI-XIII. Yüzyıllarda Türk-Gürcü Ilişkileri, Serander Yay., 2 Trabzon 2009, s.9; Tellioğlu, Osmanlı Hakimiyetine Kadar Doğu Karadeniz'de Türkler, s.30;

${ }^{12}$ Bütün bu arazide tarım ürünlerinin bol ve meyve ağaçlarının verimli olduğu aktarılmaktadır. bk. Strabon XI. 14. 4-5, p. 268.

${ }^{13}$ P'awstos Buzandac'i's' History of the Armenians, (trans. Robert Bedrosian), New York 1985, 450. p.174, 5-15. p. 232.

${ }^{14}$ Hewsen, The Geography of Ananias of Sirak (Asxarhac'oyc'), p. 65-65A; M.Fahrettin Kırzıoğlu, Ananias'ın Gugark Bölgesi'ni oluşturan vilayetlerini şöyle açıklar: Armenia (Yukarı eller) Coğrafyası'nda, eski Gogaren Eyaletine Gugar'k (Gugarlar) denilerek, 9 sancağın adları veriliyor. 1. Kolp Deresi (Kazak Çayı́nın sağdan Kür'e karıştığı yer); 2. Çor-Cor Dersi (merkezi Orbet/Şamşolde olan ve adını Çor/Şor denen Türk uruğundan alan, Orbelyanlar'ın merkez sancağı); 3. Çop-Deresi ( Borçalı Çay kaynaklarındaki Penbek kesimi, adını, Sagıstanlı olup, 590 da Sasanlı tahtını ele geçirmek isterken yenilince de Göktürklere sığınan Bahram Çoban'ın mensup olduğu Sakaların Çop-Çopin boyundan almışır; Göktürklerin batsında da Altı-Çop birliği vardır); 4. Terel'k (Tiflis güneybatısındaki Tryalet kesimi); 5. Taşır (Merkezi Lori/Loru kalesi olan Borçalı kemsi); 6. Kankar'k (Kankar'nı/Kankar'lar anlamında, Kars Arpaçayı başlarında, Kaygulu/Akbaba kesimi; hem Kıpçak hemde Peçeneklerde görülen Kanklı uruğunun Sakalar ile gelen kolu); 7. Çavakh/Çavakh'k (Çavaklar, Kartel memleketindeki Cavakh'et/Cavakh' yurdu, Göller ve Ahılkelek ile Çıldır gölü çevresi); 8. Artahan'k (Ardahanlar anlamında: Büyük/karaArdahan, Meşe- Ardahan/Khanak, Küçük Ardahan/Göle ve Khoçuvan); 9. Kalarç'k (Kalarçlar anlamında, Kertel kaynaklarında K(a)larç'et/Kalarç-Yurdu: Şavşat-Ardanuç-Artvin- Borçka kesimi. M. Fahrettin Kırzıoğlu, Yukarı-Kür ve Çoruk Boyları́nda Kıpçaklar, TTK Yay., Ankara 1992. s.197,198.

${ }^{15}$ Heinrich Hübschmann ise bu ismi Gugaraçik, Gagaraçik, Gugarkh, Gogark ve Gugark olarak vermiştir. Heinrich Hübschmann, Die Altarmenischen Ortsnamen, Amsterdam 1969, p.275,276. 
${ }^{16}$ isim Strabon'da Hyspiratis olarak geçmekte ve bölgede altın madenin bulunduğunu aktarmaktadır. bk. Strabon XI. 14. 9. p. 271; Sandalgian, Histoire De L'Armenie, p.35.

${ }^{17}$ isim Strabon'da Moschic olarak geçer, Strabon XI. II. 17. p. 228; Ptolemy'de ise isim Moschici Dağları şeklinde geçer. bk. The Geography by Claudius Ptolemy, 5. Kitap. B.12, p. 123-124; Mos-San-Mossynoeci-Moschi; Doğu Anadolu'da M.Ö. XX. y.yıl kayıtlarındaki Mushki isim ile bağlantılıdır. Meskhian'lar iberia coğrafyasındaki Samtzkhe' nin yerleşimcileridir. Geniş bilgi için bk. Antonio Sagona and Claudia Sagona, Archaelogy at The North-East Anatolian Frontier I, An Historical Geography and a Field Surevt of the Bayburt Province, Paris 2004, p.65.

${ }^{18}$ Heredos, yukarıda ismi geçen halklar hakkında şunları aktarmaktadır. Moskhoilerin başlıkları ağaçtandı, kalkanları küçük, mızrakları kısa saplıydı, uçları sivri ve uzundu. Tibarenlerin, Makronların ve Mossinoiklerin silahları da Moskhoilerin ki gibiydi; şefleri Moskhoiler ile Tibarenlerin başında Ariomardos, Makronlarla Mossinoikler ise Artayktes'in buyruğu altındaydılar. Bk. Herodotos Tarihi, s.258-261,544; Kırzıoğlu, Kıpçaklar, s.193; Josef Wiesehöfer, Antik Pers Tarihi (çev. Mehmet Ali İnci), ìstanbul 2003, s.36; Robert H. Hewsen yukarıda ismi geçen hakların Kolkhis krallığını oluşturan topluluklar olduğunu iddia etmektedir. bk. .Hewsen, Armenia $A$ Historical Atlas, p. 38.

${ }^{19}$ Ksenphon, Doğu Anadolu dan geçişi ve Makronlar, Tibarenler ve Mossyoikia hakkında bk. Ksenophon, Anabasis, 140-144, 155-164.

${ }^{20}$ Klarceti Bölgesi Hakkında Geniş Bilgi için Bk. Ömer Subaşı, “Artvin ve Çevresinin Tarihi Coğrafyası", Karadeniz Incelemeleri Dergisi, Sayı:12 Bahar 2012, Trabzon, s.9-25.

${ }^{21}$ Tukharis ismini Fahrettin Kızıŏlu şöyle açıklar: Artvin de Çoruk boyundaki müstahkem ve Makedonyalı İskender ( M.Ö IV. Yüzyıl) çağında Tukhar'is kalesi ve bölge halkının Tukhar'k (Tukhar'lar) adı da Kaşdgarlı'da "Töker", Togan da Orta-Amuderya'da "Tokharistan”a da ad veren “ Anabasis'in de "Tukhar”, Sanskrit Brahma Yazıtlar'nda "Türk Kavmi Tukhar" olarak bulunduğu, Oğuz/Türkmen boyunun, bir kolundan, ikiz-Boylu ve 22 Türkmen'in 24 Boyunu tamamlayıcı “Kalarç/Kalaç'ın, eski “Gogaren/Gugar'k/Gugaret” Eyaletinin en batı sancağına ad verdiği de düşünülür. Kırzıoğlu, Kıpçaklar,, s.206.

${ }^{22}$ Kırzıoğlu Azon ismini şöyle açıklar; Göktürklerin Kağan sülalesi ile Uygur ve Basmiller Uruk Beğleri'nin de mensup bulunduğu bilinen Asina/Aşina adlı ilahi Kurt'tan türeme kutlu soydan bir kol, Sakalar ile birlikte Kür, Aras ve Çoruk boylarına da gelmişti. Bunlara Çoruh boyunda Azon/Ason (Asina) deniyordu. İskender çağında Kartlı başbuğu olan Azon ìskender ölünce Eris-Taw ( Er-Baş) unvanı ile ülkenin hakimi oldu. 1973 Artvin il Yıllı̆̆ı. s.7.

${ }^{23}$ Charles Burney-David Marshall Lang, The Peoples of The Hills (Ancient Ararat and Caucaus) London 1971, p.195; David Marshall Lang, Iran, Armenia and Georgia, The Cambridge History of Iran ,Volume 3 Part I,The Seleucid, Parthian and Sasanian Periods, Cambridge Üniversty Press 2000, p.514.

${ }^{24}$ Spaspat; Farsça Sipeh-bud yani kumandan demektir bk. Marie Félicité Brosset, Gürcistan Tarihi (Eski Çağlardan 1212 Yılında Kadar), (çev. Hrand D. Andreasyan, Not ve Yay. Erdoğan Merçil), TTK Yay, Ankara 2003, s. 23.

${ }^{25}$ Eristav, Gürcüce eri (Ordu, daha sonra halk anlamında da kullanılmaya başlamıştır) ve távi (Baş) kelimelerinin birleştirilmesiyle oluşmuştur ve zamanla mahalli idareci haline gelmiştir. ibrahim Tellioğlu, XI-XIII. Yüzyıllarda Türk-Gürcü Ilișskileri, Serander Yay., Trabzon 2009, s.12.

${ }^{26}$ Gürcistan tarihinde ismi Klarc olarak anılan, Ermeni kaynaklarında ise, yerleştikleri bölge ìskit isimlerinden türetilen adlarla kaydedilen topluluğun kökeni hakkında tek bilgi Fahrettin Kırzıoğlu’a aittir. Gürcü dilinde 'a' ünlüsünün olmadığı için bu kavmin isminin K(a)larçlar olması gerektiğini savunan yazar, yerleştikleri alan olan Artvin-Borçka-Ardanuç-Savşat sahasını ise bu dilde aidiyet belirten ek ile birlikte Halaç yurdu anlamında K(a)larcet olduğunu vurgulamakta- 
dır. Kalaçlar, Divanu Lügati't-Türk'te, Kalaç ismi ile anılan bir Türk topluluğudur. Oğuz Destan'ında Kalaçlar'dan bahsedilir. ve Şecere-i Terakime'de Kalaçlar hakkında bilgi mevcuttur. Halaç isminin "Kal aç" kökeninden türediği ortaya çıkmakta. Klarcların, Halaçlar olduğu tezinin sahibi olan yazar, Artvin-Ardanuç-Borçka-Murgul havalisindeki yer isimlerinde ve bazı coğrafi deyimlerde bölgedeki Halaçlara dair izler günümüze kadar yaşadığını belirterek ve ayrıca öteden beri, ilkbahar ile güzün, Artvin kesiminden Karadeniz'e esen kuru ve sert olup kayalıkları deviren, sisleri ve bulutları dağıtan rüzgara, Rize'den Batuma’a kadarki kıyılarda Kalaç/Kalaş Yeli denilmektedir. Çok yaygın olarak yaşayan yel adı Kalaç/Kalaş, eski Kalarç/Klarçet Bölgesi'nin hatırası olarak günümüze kadar geldiğini söylemektedir. Tabakat-1 Nasiri'de Türk topluluğunun ismi ile ilgili yapılan ayrıntılı etimolojik değerlendirmede. Hindistan'da, Afganistan'da, Orta Asya'da ve Halaçların yayıldıkları diğer bölgelerde Khalj, Khalaj, Khalac, Khilich, Khilj, Ghalzi, Ghilzais şeklinde değişik biçimde adlandırıldıkları vurgulanmıştır. Fahrettin Kırzıoğlu'nun Karadeniz araştırmaları için önemi hakkında bakınız, ibrahim Tellioğlu, "Prof. Dr. M. Fahrettin Kırzıoğlu'nun Karadeniz Türk Tarihi Araştırmalarına Katkıları”, Türk Dünyası Araştırmaları, 2009/180 Mayıs-Haziran, s. 19-38; Kırzıoğlu, Kıpçaklar, s.202; Tellioğlu, Osmanlı Hakimiyetine Kadar Doğu Karadeniz'de Türkler, s. 39,40; Sadettin Gömeç, "ilslam Öncesi Türk Tarihinin Kaynakları Üzerine", Tarih Araştırmaları Dergisi, Yıl 1999-2000, sayı 31, Ayrı Basım, Ankara 2000, s. 59; Zeki Velidi Togan, Oğuz Destanı, Reşieddin Oğuznamesi Tercümesi ve Tahlili, İstanbul 1972, s.45,46; Ebülgazi Bahadır Han, Türklerin Soykütügü, (Neş. Muharrem Ergin), s.36; Ali Kafkasyal, Iran Türkleri, Bilgeoğuz Yay., i̇stanbul 2010, s. 108,109.

${ }^{27}$ Robert W. Thomson, RewritingCauscasian History, The Medieval Armenian Adaptation of the Georgian Chronicle, The Orginal Georgian Texts and The armenian Adaptation, Oxford 1996, s.24-35; Brosset, Gürcistan Tarihi, s.16-25; Robert Bedrosian, Georgian Chronicle Juansher's Concise History of the Georgians, New York 1991, p.14-18.

${ }^{28}$ Yabancıların Artaxias-Artaksias dedikleri șahsa Ermeniler Ardaşes derler. Antiochus tarafından atanmış olan Artaxias isimli general, Antiochus'un Romalılara yenilmesinin ardından bağımsızlığını ilan etti. M.Ö.190-188. Küçük krallığını ardından Küçük Asya'nın küçük ülkeleri ile Medya ve iberia'ya doğru genişletti. bk. Esat Uras, Tarihte Ermeniler ve Ermeni Meselesi, Belge Yayınları, İstanbul 1987. s 42,43; Burney- Lang, The Peoples of The Hills (Ancient Ararat and Caucaus), p.188,189.

${ }^{29}$ Strabon XI. 14. 9, p. 269; Cyril Toumanoff, Studies in Christian Caucasian History, Georgetown University Press, Washington 1963, p.457,458; René Grousset, Başlangıcından 1071'e Ermenilerin Tarihi, (çev. Sosi Dalanoğlu), ìstanbul 2006, s.78,79; Burney-Lang, The Peoples of The Hills, p.192.

${ }^{30}$ Thomson, Rewriting Causcasian History, p.40 dip not 60.

${ }^{31}$ Esat Uras Armenia bölgesini anlatırken onbeş vilayetten meydana geldiğini ve 13. vilayetin ise Klarceti bölgesinin de içerisinde bulunduğu Gugarik'ın (Gogarene) olduğunu belirtmiştir ve sınırlarını : Dayk'ın doğusunda, Ararat ve Siyunik'in kuzeyinde Kur nehri çevresinde, Eşkanilerden sonra İran hükümdarları zamanında, Pteşh unvanlı askeri bir kumandanla idare olunan ve önemli şehirleri ise Ardahan, Çıldır, Ahilkelek, Ardanuç, Şavşat ve Lori şehirleri idi. Uras, Tarihte Ermeniler ve Ermeni Meselesi, s.18,20.

${ }^{32}$ Arsas, Eșkani hükümdarlarına verilen ismidir, Ermenilerce Arsas-Arşak, Valarsas-Vagarşak'tır. Valarsas yahut Vagarşak, V. Arsas'ın (Mithidates 1.) kardeşidir. Bir rivayete göre de oğludur. Valarsas, Arşak tarafından Armenia hükümdarı yapılmış ve bu bölgede Eşkaniyan sülalesinin kurucusu olmuştur. Father Michael Chamich, History of Armenian, From B.C. 2247 to the of Christ 1780, or 1299 of the Armenia Era, (trans. Johannes Avdall), Calcuta 1827, p.58; Uras, Tarihte Ermeniler ve Ermeni Meselesi, s.23. dip not 1. 
${ }^{33}$ Moses Khorenats'i, bu konuyu özetle şöyle aktarmaktadır: İran ve Partlar'ın hükümdarı ve aslen Part olan büyük Arşak, hakimiyetini Asur devleti üzerine kurdu, Nineva kralı oldu ve bütün dünyayı idaresi altına aldı, Armenia tahtına da kardeşi Vagarşak'ı geçirerek Nusaybin, Filistin, Küçük Asya, Pontos, Kafkasya, Azerbaycan memleketlerini ve daha bir çok yerleri verdi. Arşak birici ve Vagarşak da ikinci Arsas oldu. bk. Moses Khorenats'i History of the Armenians, (trans. Robert W.Thomson), London 1980, p. 81-83; Uras, Tarihte Ermeniler ve Ermeni Meselesi, s. 21,2; Chamich, History of Armenian, p. 58-60.

${ }^{34}$ Moses Khorentes'e göre, Armenia karlı Tayk ve Kogh ( Göle) de yaz eğlenceleri ve av sahaları düzenlemiş, Kafkas eteklerindeki sakinlerinin eşkıyalıklılarını önlemek içim şiddetli tedbirler almış, Gugark eyaletine gelince, Mihrdat isimli birisini buraya vali olarak tayin etmiştir. Moses Khorenats'i History of the Armenians, p. 135-140; Brosset, Gürcistan Tarihi, s.29 dip not 158.

${ }^{35}$ Brosset, Gürcistan Tarihi, s. 31; Kırzıoğlu isimlerin Türkçe oluğunu belirtiyor. Kırzıoğlu, Kıpçaklar, s.198.

${ }^{36}$ Cyril Toumanofff, “Caucasia and Byzantium”, The Journal Traditio 27 (1971), p.116.

${ }^{37}$ Tigranes ile Roma arasındaki savaş için bk. Chamich, History of Armeni, C.l. p. 68-84.

${ }^{38}$ Gürcü dilindeki Adcharistsqali diye tanımlanan Absarros Irmağı Çoruh Irmağı ile birleșerek Gürcistan da ki Absarros ( Gonio) Kalesi önünden Karadeniz'e dökülür. bk. Arrianus'un Karadeniz Seyahati, s.59.

${ }^{39}$ Murat Arslan, Roma'nın Büyük Düşmanı Mithradates VI Eupator, Odin Yayıncılık, ìstanbul 2007, s. 464-476; Lang, Gürcüler, s. 73,74; Nikoloz Berdzenişvili-Simon Canaşia, Gürcistan Tarihi ( Başlangıçtan 19. Yüzyıla Kadar,) (çev. Hayri Hayrioğlu), Sorun Yayınlar, İstanbul 2000, s. 61,62; Burney- Lang, The Peoples of The Hills, p.195.

${ }^{40}$ Ermeni Kronolojisinde Arşak ismi Abrak olarak geçmektedir. bk. Thomson, Rewriting Causcasian History, s. 43; Fahrettin Kırzıoğlu bu sülale hakkında şunları söylemektedir: M.Ö. 93-33 yılları arasında 1. Arşaklı sülalesini ỉberya/Karlı ülkesine kuran Dede-Oğul-torun'un isimleri Türkçedir: Arşak (93-81) Artak yani Artuk, Bartom (Varyant Bartom), Eski Türkçede Arşak/ Erşek: Pars ile Ayı arasında yırtıcıdır. bk. Kırzıoğlu, Kıpçaklar, s.198 dip not 12.

${ }^{41}$ Toumanoff, Studies in Christian Caucasian History, p.458.

${ }^{42}$ Aderk dönemine kadar tek kral tarafından yönetilen iberia toprakları Aderk tarafından ilk defa iki oğlu arasında paylaştırıldı. Aderk, Mtzheta'yı ve bütün memleketini onlar arasında taksim ederek, büyük oğlu Bartom' Şida-Kartlı'yı Munhar'ın yanında bulunan memleketi ve Kür Nehrinin doğusunda Heret'e ve Kartlı ve Egris'in medhaline kadar olan bölgeyi; Küçük oğlu Kartam'a da, Armaz, Kür Nehrinin güneyinde, Hunan'dan nehir kaynağına kadar olan toprakları ve Klarcet'i verdi. Thomson, Rewriting Causcasian History, p.52,57; Brosset, Gürcistan Tarihi, s. 42,43-48; Toumanoff, Studies in Christian Caucasian History, p.458.

${ }^{43}$ Thomson, Rewriting Causcasian History, p.67; Brosset, Gürcistan Tarihi, s. 54,55.

${ }^{44}$ Brosset, Gürcistan Tarihi, s.60, 61.

${ }^{45}$ Vitaxate (Askeri Naiplik) hakkında bk. Hewsen, Armenia A Historical Atlas, p. 43.

${ }^{46}$ Agathangelos History of The Armneians, Trans and Commen. R.W. Thomson, State University of New York Press 1976, p.377; Toumanoff, Studies in Christian Caucasian History, p.458460, dip not. 98.

${ }^{47}$ Berdzenişvili-Canașia, Gürcistan Tarihi, s. 85,86.

${ }^{48}$ Roma devleti, 363'de (Joian Barışı) Artaxata (Artashat) ve bunun ötesindeki arazisinden feragat etmek zorunda kaldı. Ancak Armenia ve íberia bölgeleri esasen doğrudan doğruya Roma arazisi olmayıp, sadece Romalıların askeri himayesinde bulunmaktaydılar. Ancak iki imparatorluk arasındaki çekişmenin yoğunlaştığı bir sırada 363 de Julian'ın (361-363) sefer sırasında ki ölümü, İranlılar tarafından Nisibis (Nusaybin - 298) Antlaşması ile kaybedilen yedi bölgenin dördünün 
geri alınmasına ek olarak Gogarane bölgesi ile birlikte ona komşu olan bölgeler, Armenin ve iberia ile Albania bölgesinin himayesini Il Şapur'a (309-379) bırakması için, Julian'ın haleflerini zorladı. Cyril Toumanoff, "Armenia and Grorgia", The Cambridge Medieval History, vol. IV, The Byzantine Empire part I, Cambridge 1966, p.595; Ronald Grigor Suny, The Making of the Georgian Nation, Indiana Universty Press 1994, p.21,22; Hewsen, Armenia A Historical Atlas, p. 71; W.E.D. Allen, A History of The Georgian People, London 1932, p.76; Ernst Honigmann, Bizans Devletinin Doğu Sınırı, (çev. Fikret lşıltan), ìstanbul 1970, s.4,5; Geoffrey Greatrex and Samuel N.C.Lieu, The Roman Easern Frontier And The Persian Wars (Part II A.D. 363-630), London and new York 2004, p.1; Toumanofff, Caucasia and Byzantium, p.116.

${ }^{49} 387$ yılında yapılan Roma-Pers anlaşması sonrası 600'e kadar bir daha önemli ölçüde değişmeyecek şekilde Garin ( Erzurum)'in ve Martyropolis'in (Miyafarikin-Silvan) doğusundan geçiyordu. Garin ve Martyropolis Bizans sınır şehirleri oluyordu. iki devlet arasındaki Aşkale-Erzurum Ovasını, Pasinler ovasından ayıran ve tarafların birbirlerine saldırabilecekleri çok uygun bir koridor şeklindeki Deva Boynu sırtında geldi. Bu aşamadan sonra daha kuzeye deki Doğu Roma sınırların içerisindeki yukarı Çoruh nehri havzasından, Tortum-Oltu (Tao) bölgesi ile bölünüyordu. Tao, Yusufeli dolaylarında Çoruh vadisinin bir bölümünü kapsayan sınır; Yusufeli, ìspir arasından Çoruh vadisini geçiyor ve Kaçkar Dağları'na ulaşıyordu. bk. Grousset, Başlangııından 107l'e Ermenilerin Tarihi, s.160; Savaș Eğilmez, "Karin Bölgesi Ve Thoedosiopolis'in Kuruluşu", A. Ü. Türkiyat Araştırmaları Enstitüsü Dergisi, Sayı 33 Erzurum 2007, s. 184.

${ }^{50}$ Lang, Gürcüler, s. 86,87.

${ }^{5 l}$ Thomson, Rewriting Causcasian History, p.67; Brosset , Gürcistan Tarihi, s. 147; Toumanoff, Studies in Christian Caucasian History, p.460.

${ }^{52}$ The Roman History of Ammianus Marcellinus: During the Reigns of the Emperors Constantius, Julian, Jovianus, Valentinian and Valens, (trans. Charles Duke Yonge), London 1894, 27.12-1617, p. 466 ; Toumanoff, Studies in Christian Caucasian History, p. 461 din not 103; Brosset, Gürcistan Tarihi, s. 107 dip not 458; Suny, The Making of the Georgian Nation, p.21,22; Allen, A History of The Georgian People, p.76; Toumanoff, "Armenia and Grorgia", p.595.

${ }^{53}$ Thomson, Rewriting Causcasian History, p.150-153; Brosset, Gürcistan Tarihi, s. 113; Toumanoff, Studies in Christian Caucasian History. p. 461 dip not. 109.

${ }^{54}$ Kurt başlı, Gürcüler tarafindan geleneksel olarak Gurgaslan olarak yazılır. Ancak isim Türkçe Gurgi Arslan -Georgian Aslan- kelimesinin bir kombinasyonu olarak görünmektedir. Ayrıca Vakhtang isminin orjini ise Varan-Khusraw-Tang dir. Allen, A History of The Georgian People, p.77 dip not 1; Toumanoff, Studies in Christian Caucasian History, p. 378;Vahtang'a İranlıların Kurt başı adını vermelerinin nedeni,Vahtang'ın savaş sırasında Kurt başlı resimli maske kullanmasıydı. Berdzenişvili-Canaşia, Gürcistan Tarihi, s.90.

${ }^{55}$ Thomson, Rewriting Causcasian History, p.152; Suny, The Making of the Georgian Nation, p.23,24; Toumanoff, Studies in Christian Caucasian History, p. 462 dip not. 113; Toumanoff, "Armenia and Grorgia", p. 600.

${ }^{56}$ Thomson, Rewriting Causcasian History, (Juanser: Life of Vaxt'ang Gorgasali), p.194; Tsarevitch Wakhoucht, Descriptiion Geographique de la Georgian, (trans. M. Brosset), S.Petersbourg 1842, p.111; Brosset, Gürcistan Tarihi, s. 143; Hewsen, Armenia A Historical Atlas, p.86.

${ }^{57}$ Suny, The Making of the Georgian Nation, p.25.

${ }^{58}$ Lang, Gürcüler, s 89,90.

${ }^{59} 572$ deki Armenia isyanı hakkında bk. Robert W. Thomson, The Armenian History Attributed to Sebeos, translated, with notes; Sebeos History, Liverpool 1999, p.7; Grousset, Başlangıcından 107l'e Ermenilerin Tarihi, s.234-239; Fahrettin Kırzıoğlu, Kars Tarihi, ìstanbul 1953, s.200.

${ }^{60}$ Suny, The Making of the Georgian Nation, p.25; Berdzenişvili-Canașia, Gürcistan Tarihi, s.106. 
${ }^{61}$ Georg Ostrogorsky, Bizans Devleti Tarihi, (çev. Fikret lşıltan), TTK. Yay., Ankara 2006, s. 73.

${ }^{62}$ Paul Lemerle, Histoire de Byzance -Bizans Tarihi-, (çev. Galip Üstün), İstanbul 2006, s. 69.

${ }^{63}$ Thomson, Rewriting Causcasian History, p.229; Brosset. Gürcistan Tarihi, s. 180, 186; Toumanoff, Armenia and Grorgia, p.603; Suny, The Making of the Georgian Nation, p.21,22.

${ }^{64}$ Toumanoff, Studies in Christian Caucasian History, p. 464,465.

${ }^{65}$ Thomson, The Armenian History Attributed to Sebeos, p.18-24; Honigmann, Bizans Devletinin Doğu Sinırı, s. 26,27; Grousset, Başlangıcından 107ı'e Ermenilerin Tarihi, s.240.

${ }^{66}$ Thomson, The Armenian History Attributed to Sebeos, p.18-24; Sebeos, Patmitiwn Sebeosi Episkoposi Herakin; Sebeos History, (çev. Robert Bedrosian), New York, 1985, p.41; Honigmann, Bizans Devletinin Doğu Sınırı, s.26,27; Kırzıoğlu, Kars Tarihi, s.202.

${ }^{67}$ Grousset, Başlangıcından 107ı'e Ermenilerin Tarihi, s. 240,241; Thomson, The Armenian History Attributed to Sebeos, p.18-24, Sebeos; Patmitiwn Sebeosi Episkoposi Herakin; Sebeos History, p.4l; Bishop John Mamikonean's History of Taron, Venice, 1889 (Yovhannu Mamikoneni episkoposi Patmut'iwn Taronoy), (çev. Robert Bedrosian), New York 1985, p.9,10.

${ }^{68}$ Göktürkler hakkında geniş bilgi için bk., Ahmet Taşağıl, Gök-Türkler, TTK. Yay., c .l,Il,Ill, Ankara 2000

${ }^{69}$ Thomson, The Armenian History Attributed to Sebeos, p.34,45; Ostrogorsky, Bizans Devleti Tarihi, s. 73; Honigmann, Bizans Devletinin Doğu Sınırı, s.27.

${ }^{70}$ Grousset, Başlangıcından 107ı'e Ermenilerin Tarihi. s.242,243; Kırzıoğlu, Kars Tarihi, s. 202,203

${ }^{71}$ Stefanos, gerek İranlılar gerekse Bizanslılardan korktuğundan dolayı kral unvanını almağa cesaret edemediğinden, kendisine eristavlar mtavarı (eristav şefi- arşidük ve dükler presni) deniliyordu. Brosset, Gürcistan Tarihi, s. 189; Suny, The Making of the Georgian Nation, p,26.

${ }^{72}$ Ostrogorsky, Bizans Devleti Tarihi, s. 77.

73 Bishop John Mamikonean's History of Taron, p.11,12; Grousset, Başlangıcından 107ı'e kadar Ermenilerin Tarih, s.260.

${ }^{74}$ Walter E.Kaegi, Bizans ve ilk islam Fetihleri, (çev. Mehmet Özay), i̇stanbul 2000 s. 278; Ostrogorsky, Bizans Devleti Tarihi, s.86; A.A. Vasiliev, Bizans Imparatorluğu Tarihi, (çev. Arif Müfid Mansel), Ankara 1943, c.l, s.246,247.

${ }^{75}$ Yapılan bu anlaşma teşebbüsü hakkında bk. Thomson, The Armenian History Attributed to Sebeos, c.l, p.66, c.ll, p.202,203.

${ }^{76}$ Bishop John Mamikonean's History of Taron, s.64; Vasiliev, Bizans Imparatorluğu Tarihi. s. 250,251; Romilly Jenkins, Byzantium, The Imperial Centuries A.d. 610-1071, New York: Random House 1966, p.22.

${ }^{77}$ Ostrogorsky, Bizans Devleti Tarihi, s.95; Thomson, The Armenian History Attributed to Sebeos, p.78; Sebeos, Patmitiwn Sebeosi Episkoposi Herakin; Sebeos History, p. 103.

${ }^{78}$ Yapılan bu anlaşma hakkında bk. Vasiliev, Bizans Imparatorluğu Tarihi, s.252,253; Jenkins, Byzantium, The Imperial Centuries A.d. 610-1071, p.24,25; Ostrogorsky, Bizans Devleti Tarihi, s. 95.

${ }^{79}$ Gürcü kaynaklarında anlatılan bu olaylar, İmparatorun 623 yılı sırasındaki Lazistan'a yapılan sefer sırasında vuku bulmuş olması muhtemeldir. Ancak Erdoğan Merçil'in eserinde Stefanos'un hakimiyet yılları 600-619 yılları arası verilmiştir, Bedrosian ise çevirisinde Stefanos'un hakimiyetini 602-627 yılları arasında vermiştir ki imparatorun 623 yılı seferini sırasında Stefanos'un öldürüldüğü için bu tarihlerin daha doğru olma olasılı̆̆ daha muhtemeldir. Brosset, Gürcistan Tarihi, s. 189; Bedrosian, Georgian Chronicle Juansher's Concise History of the Georgians, p. 88.

${ }^{80}$ Kırzıoğlu bu ismin rütbe adı olduğunu belirtmiş ve Cabgu/Yabgu olarak vermiştir. Kırzıoğlu, Kıpçaklar, s.217; Bedrosian, ismi Jebu olarak vermiştir. Bk. Movses Dasxurants'i'sHistory of the 
Aghuans, (translated from Classical Armenian by Robert Bedrosian), Book 2, B. 11. p.65,http://rbedrosian.com/md7.htm\#ll; Kalankatlı Moses'in eserinde bu isim şöyle geçer: Hazarlar dağ geçitlerini aşıp üç ülkeye Ermeniye, iberya ve Albanya'ya gelip çıktılar ve onlar bu yerlerde durdukları zaman felaketli kuzet arslanı Cebu hakandan yavrusu Şad'a gamlı bir haber geldi. Kalankatlı Moses, Alban Tarihi ve Alban Salnamesi, ( Rusça ve İng.'den Azerbaycan Türkçesine Çeviri Ziya Bünyadov, Türkçe çev. Yusuf Gedikli), Selenge Yay., İstanbul 2006, s.179.

${ }^{81}$ Thomson, Rewriting Causcasian History, p.232-236; Brosset, Gürcistan Tarihi, s. 189-194; Bedrosian, Georgian Chronicle Juansher's Concise History of the Georgians, p.88,89; Lang, Hazar Kağanı Cibğu ile İmparatorun ilk Tiflis kuşatmalarını ve kuşatma sırasında halkın Cibğu ve imparatorla alay etmelerini 626 yılında gerçekleştiğini, Bir yıl sonra 627 yılında ise Cibğu'nun şehri ve kalesini aldığını ardından kale komutanlarını öldürerek imparatora gönderdiğini iddia eder. Lang, Gürcüler, s.91,92; Allen, A History of The Georgian People, p.79; Grousset, Başlangıcından 107ı'e Ermenilerin Tarihi, s. 264; L.N. Gumilev, Hazar Çevresinde Bin Yıl, (çev. Ahsen Batur), Selenge 2003, s.210,211

${ }^{82}$ el-Belazuri, Fütühu'l Büldan, (çev. Mustafa Fayda), Kültür Bakanlığı Yay., Ankara 2002, s. 290; ibnü'l- Esir, El-Kâmil fi't-Tarih, C.Ill Bahar Yayınları, s.88-91; Ebũ Cafer Muhammed Bin Cerir'üt- Taberi, Tarih-i Taberi, (neş. M.Faruk Gürtunca), C.IIl, İstanbul, s.491; Mirza Bala, "Gürcistan", İslam Ansiklopedisi, Cilt: IV, Milli Eğitim Basım Evi, İstanbul 1987, s. 838. 